\title{
Marii Dąbrowskiej listy z podróży dookoła Europy w 1935 roku
}

Szesnaście listów Marii Dąbrowskiej z turystycznego rejsu s/s „Kościuszko” dookoła Europy w 1935 roku jest niewielkim fragmentem czekającej na druk, liczącej tysiąc pięćdziesiąt dwa listy korespondencji z lat 1924-1951 z wieloletnim towarzyszem życia pisarki, Stanisławem Stempowskim¹.

Poznali się przez męża pisarki, Mariana Dąbrowskiego, którego łączyły ze Stempowskim powiązania wolnomularskie, ale zaczęli pisywać do siebie kurtuazyjne listy, jeszcze zanim dane im było spotkać się osobiście. Po śmierci Dąbrowskiego w 1925 roku zbliżyli się do siebie, w połowie następnego roku oboje zrozumieli, że połączyło ich głębokie uczucie, mimo różnicy wieku blisko dwudziestu lat. W 1927 roku zamieszkali razem w mieszkaniu Dąbrowskiej przy Polnej. Odtąd ich losy były nierozerwalnie splecione aż do śmierci Stanisława Stempowskiego w 1952 roku, choć nigdy nie rozwiódł się on z żoną Marią ze Stempowskich Stempowską, z którą był w separacji od śmierci najmłodszego syna Pawła w 1920 roku, ale z którą przyjaźnił się i roztaczał nad nią opiekę, zwłaszcza w czasie okupacji.

Sztuka Edycji 1/2017 ISSN 2084-7963 (print) ISSN 2391-7903 (online) s. $167-191$
Edycja całości korespondencji została przygotowana do druku w ramach projektu UMO-2011/01/B/HS2/03285, finansowanego przez Narodowe Centrum Nauki. 
W sierpniu 1935 roku Dąbrowska planowała wyjechać wraz z bratem, Bogumiłem Szumskim, na wycieczkę turystyczną do Sztokholmu, zgłosiła się jednak zbyt późno, gdy wszystkie miejsca były już zajęte. W tej sytuacji wybrała się samotnie na wycieczkę dookoła Europy statkiem „Kościuszko”. Rejs trwał od 10 do 30 września. Eskapada, choć chwilami ekscytująca, szybko zaczęła ją męczyć. Już po tygodniu podróży notowała w Dziennikach, prowadzonych przez jakiś czas także w trakcie rejsu: „[...] zaczynam uczuwać znużenie z powodu zgiełku i życia w tłumie. Chciałabym już być w domu na Polnej” (Dzienniki, zapis z 17 września 1935 roku). Spotkani na statku znajomi na dłuższą metę rozczarowywali. Wśród uczestników rejsu byli także: Maria Pawlikowska-Jasnorzewska z mężem, profesor Manfred Lachs, Paulina Appenszlak, Władysław Rymkiewicz i Artur Maria Swinarski, który zadedykował Dąbrowskiej napisany w czasie podróży wiersz Oczy nad Pireusem. Dąbrowska wspominała po latach w liście do Kazimierza Wierzyńskiego: „[Swinarski] zadedykował mi wiersz napisany w 35 r. w Sewilli, gdzie byliśmy jednocześnie, ale bynajmniej nie razem, w czasie wycieczki statkiem”2. Rymkiewicz wspominał początek podróży: „[...] pierwszą osobą, którą spotkałem na pokładzie wcześnie rano, była Maria Dąbrowska, znana mi już przedtem z towarzystw warszawskich, gdzie widywałem ją u naszych wspólnych znajomych. Maria Dąbrowska była naprawdę uroczą niewiastą. Bardzo prosta, nie miała w sobie absolutnie żadnej wyniosłości, a już przecież wydała Noce i dnie i otrzymała Państwową Nagrodę Literacką"

„Kościuszko” wypłynął w morze z Gdyni przy dźwiękach Marsza Pierwszej Brygady, granego przez orkiestrę pokładową. Trasa prowadziła przez Morze Północne (tu śluzowanie w Holtenau), następnie Kanał Kiloński z postojem w Antwerpii, skąd pociągiem uczestnicy pojechali na jeden dzień do Brukseli. Następnie, 15 września, statek przepływał przez Pas de Calais i kanał La Manche, w dzień później był już na Atlantyku, kierując się do Kadyksu, do którego dopłynął 20 września. Zwiedziwszy miasto, uczestnicy wycieczki pojechali pociągiem do Sewilli, gdzie oglądali katedrę i Alkazar z jego ogrodami. Wracali do Kadyksu taksówkami przez miejscowości Jérez de la Frontera, Puerto de Santa Maria i San Fernando. Dalszym etapem rejsu była cieśnina Gibraltaru i trasa wzdłuż Afryki. Do brzegu przybili w Algierze, skąd wyjechali na wycieczkę do miasta Blida i w góry Małego Atlasu. Dwudziestego piątego września statek wpłynął na wody Morza Jońskiego, następnie Morza Egejskiego, kierując się ku Pireusowi. Pisarka miała w tym czasie okazję zobaczyć maszynownię statku i mostek kapitański. Do Pireusu statek dopłynął 26 września. Turyści mieli jeszcze w programie wycieczkę do Aten, po czym statek wracał do kraju przez Morze Egejskie, Dardanele, Morze Marmara i Stambut.

Listy odgrywały niezwykle istotną rolę w życiu Dąbrowskiej; pisała dużo i na wszystkie otrzymane przesyłki odpowiadała. Także Stempowski czuł przemożną potrzebę kontaktu listowego z najbliższymi. Dzień po jej wyjeździe planował z typową dla siebie pedanterią: „Pisać będę co drugi dzień, w parzyste liczby, a więc do Kadyksu 12 i 14 (Nr 2 i 3), do Algieru 15, do Pireusu 16 i 18, do Stambułu 20 i do Konstancy 22, 24 i 26”4. „Myślę o tym, jak dawniej zesłańcy na Syberii otrzymywali listy po czterech miesiącach, czyli na odpowiedź czekali osiem miesięcy"s - pocieszał się, spodzie-

2 List do Kazimierza Wierzyńskiego z 29 stycznia 1962 roku. Druk: „Kultura” 1978, nr 5, s. 13.

${ }^{3}$ W. Rymkiewicz, Rozumienie historii i skromność słowa, rozmawiał J. Rzymowski, „Literatura” 1980, nr 20

${ }^{4}$ List z 11 IX 1935. Muz. Lit., sygn. 2071, t. 3, k. 87.

${ }^{5}$ List z 20 IX 1935. Muz. Lit., sygn. 2071, t. 3, k. 101. 
Relacje z wyprawy Dąbrowska zapisała w listach do Stempowskiego, a częściowo także w dzienniku wając się nieregularnej korespondencji od Dąbrowskiej. W listach relacjonował sprawy ważne i drobne - wyniki wyborów parlamentarnych w Polsce, koncert fortepianowy w radio, awanturę między Boyem i Kadenem-Bandrowskim w „Kurierze Porannym” oraz smak duszonych kurżetek i inicjatywy służącej w kwestii przetworów. Ale głównie zależało mu, by adresatka otrzymywała z domu „znaki życia”.

Oboje numerowali swoje listy, przykładając ogromną wagę do faktu ich dotarcia do adresata; Dąbrowska myliła się w tych adnotacjach, Stempowski wprowadzał własną numerację otrzymanych przesyłek, listy są więc często opatrzone podwójną numeracją, co ułatwia edytorowi sprawdzenie kompletności zachowanej korespondencji.

Relacje z wyprawy Dąbrowska zapisała w listach do Stempowskiego, a częściowo także w dzienniku (przerwała notatki 17 września), po czym po powrocie wykorzystała je w opublikowanych w 1935 roku w „Wiadomościach Literackich” Listach z podróży $\left(\mathrm{nr} 47\right.$, s. 5) ${ }^{6}$. Była to forma literacka bliska pisarce - już w latach studiów zagranicznych publikowała w 1910 roku w „Zaraniu” Listy z Belgii i Notatki z wycieczki po Belgii. Posiłkując się zapisami dziennika i listami wysyłanymi do Stempowskiego, opracowała Dziennik podróży do Jugostawii w 1934 roku, który w 1964 roku włączyła do Pism rozproszonych'.

Warto dodać, że zapiski Dziennika pisarki w wielu fragmentach są niemal dosłownym powtórzeniem obszernych fraz listów. Mamy tu więc kolejne, różne warianty tego samego tekstu: zapis w dzienniku - list - tekst podany do druku w czasopiśmie (dopracowany stylistycznie i pogłębiony na poziomie refleksji). Jest to zresztą w przypadku Dąbrowskiej sytuacja nie tak znowu rzadka; pisarka traktowała dziennik także jako notatnik, do którego sięgała, przetwarzając jego zawartość na utwór literacki, czasem też list. W tym przypadku, zapewne z powodu braku czasu na prowadzenie dziennika w czasie podróży - to przede wszystkim listy do Stempowskiego stały się takim notatnikiem. Publikacji w „Wiadomościach” nie możemy jednak traktować jako pierwodruku listów; są zasadniczo przeredagowane, choć bez trudu daje się zlokalizować obszerne i liczne autocytaty. Listy, poddane znaczącym zmianom stylistycznym i redakcyjnym, zyskały tu formę reportażu.

Jest jeszcze jedna edytorsko ciekawa sprawa. Po upadku powstania warszawskiego pisarka przebywała w Dąbrowie Zduńskiej, gdzie na maszynie, przywiezionej jej z Polnej przez Stanisława Lorentza, w okresie od października 1944 do stycznia 1945 roku sporządziła odpisy swoich listów, w tym około dwustu listów z lat 1926-1939 do Stempowskiego, dokonując w nich wielu zasadniczych zmian, w tym opuszczeń znacznych fragmentów. W większości odpisy te są przechowywane w Muzeum Literatury im. Adama Mickiewicza (sygn. 2051), nieliczne w Bibliotece Uniwersytetu Warszawskiego (sygn. 1565). W Muzeum Literatury w Warszawie odpisy są przechowywane w kartonowej obwolucie, którą Stempowski zatytułował: „Listy Maryjki osobiste. 1928-1935”; znajduje się tu też napisana jego ręką sentencja: „Nie słowo ciałem, lecz ciało słowem stać się musi, by zyskać nieśmiertelność”; w tej edycji istnienie odpisu odnotowano w metryce listu.

Przepisując swoje listy, Dąbrowska usuwała wątki osobiste i personalne, emocjonalne apostrofy i wzmianki o sprawach domowych. Te redakcyjne zabiegi miały służyć przyszłej publikacji korespondencji. Listów Stempowskiego Dąbrowska nie przepisa-

Przedruk pt. Listy z podróży (fragmenty listów), w: M. Dąbrowska, Pisma rozproszone, t. 1, Kraków 1964, s. 397-415. Eadem, Dziennik podróży do Jugosławii w 1934 roku i Podróż do Jugosławii, w: ibidem, s. 374-396 i 416-454. 
ła; nie wiemy, czy uznała, że przyszła edycja powinna obejmować jedynie jej listy, czy też - tym razem powstrzymywała się przed ingerowaniem w listy korespondenta (tych zahamowań nie miała w odniesieniu do listów zmarłego w 1925 roku męża) ${ }^{8}$, a może po powrocie do Warszawy zaniechała tej pracy w wirze ponownej organizacji trudnego, powojennego życia na Polnej.

Rękopisy korespondencji Marii Dąbrowskiej i Stanisława Stempowskiego są przechowywane w Muzeum Literatury im. Adama Mickiewicza (sygn. 2050, 2071) oraz w Gabinecie Rękopisów Biblioteki Uniwersytetu Warszawskiego (sygn. 1564, 1389) w Warszawie; tutaj w metryce listów zastosowano skróty: Muz. Lit., BUW, określające miejsce ich przechowywania.

Publikowane tu listy zostały poddane pewnym zabiegom porządkującym. Ujednolicono pisownię nazw własnych, milcząco poprawiono literówki, zmodernizowano pisownię, a zwłaszcza interpunkcję, jako że pisarka nagminnie używała myślników zamiast przecinków. Nawiasy graniaste stosowano przy ingerencjach edytorskich: podawano w nich miejsce nadania listu, jeśli Dąbrowska tego nie odnotowała, w słowach zapisanych skrótem oraz przy rekonstrukcji datowania listu. Odmiennie niż w oryginale, tytuły zapisano kursywą. Wszystkie cytaty z języków obcych tłumaczono na polski. Zachowano podkreślenia pochodzące od autorki listów (pogrubienie czcionki).

Cytaty z Dzienników Dąbrowskiej pochodzą z ostatniej ich edycji: M. Dąbrowska, Dzienniki 1914-1965, pierwsze pełne wydanie w trzynastu tomach (bez opracowania edytorskiego) pod kierunkiem Tadeusza Drewnowskiego, Warszawa 2009; odwołując się do nich w przypisach stosowano skrót: Dz. wraz z datą zapisu, np.: Dz. 28 X 1935, przy niedatowanych Uzupetnieniach Dzienników zapis: DzU, t. 3.

$1 \mathrm{a}^{*}$

[Gdynia, 10 IX 1935]**

Jak było do przewidzenia, w pociagu był tłok nieopisany, wszyscy na „Kościuszkę”. Dopiero gdy już w przedziale nie można było szpilki wetknąć, konduktor zawiadomił, że są trzy specjalne wagony dla wycieczki „Kościuszki”. Rozrzedziło się nieco, ale było nas w przedziale sześć osób. Nie zmrużyłam oka i obserwowałam w sinym światełku środkowej lampy współpasażerów. Śpiący w najdziwaczniejszych pozach, sprawiali widok wnętrza pociągu po ciężkiej katastrofie kolejowej. Zwłaszcza „maquillage” na obliczach czterech śpiących dam sprawiał koszmarne wrażenie. Świt był cudownie czysty, choć b[ardzo] zimny, ale Gdynia przywitała nas rzęsistą ulewą. Siedzę w kawiarni dworca i piję śniadanie, rzeczy moje są już na statku. Spotkałam już dwie znajome, dziennikarkę p. Krawczyńską i... panią Appenszlakową.

Serdeczności,

M.

${ }^{8}$ Por. Ich noce i dnie. Korespondencja Marii i Mariana Dąbrowskich 1909-1925, wstęp i oprac. E. Głębicka, Warszawa 2005. 
[Karta pocztowa; na awersie fot.:] Gdynia. Okręt szkolny „Dar Pomorza”; [adres:] WPan Stanisław Stempowski, Warszawa, Polna 40 m. 31; [stempel pocztowy:] Gdynia 5. 10 IX 35; [dopiski ręką Stempowskiego:] 10 IX 35. 1-a. Muz. Lit., sygn. 2050, t. 4, k. 104 .

\section{Objaśnienia}

* Numer dopisany ołówkiem ręką Stanisława Stempowskiego.

** Data według stempla pocztowego.

10

p. Krawczyńską - Jadwiga Krawczyńska (1891-1975), dziennikarka, w okresie międzywojennym współpracowniczka „Dziennika Porannego” i „Dziennika Powszechnego”

panią Appenszlakową - Paulina Appenszlak-Fogiel (?-1976), literatka, działaczka społeczna, żona redaktora „Naszego Przeglądu", Jakuba Appenszlaka (1894-1950)

Za chwilę zaczniemy się zaokrętowywać. Zaświeciło słońce. Piękna pogoda. Jedzie Wojciech Kossak, ojciec Pawlikowskiej, ale nie wiem, co będzie malować, chyba morskie konie.

S[erdeczności], M.

[Karta pocztowa; adres:] WPan Stanisław Stempowski, Warszawa, Polna 40 m. 31; [stempel pocztowy:] Gdynia 5. 10 IX 35. Muz. Lit., sygn. 2050, t. 4, k. 105; odpis masz., sygn. 2051, k. 92.

Objaśnienia

* Numery dopisane ołówkiem ręką Stempowskiego.

1-2 Jedzie Wojciech Kossak - Wojciech Kossak (1856-1942), syn Juliusza, malarz. Dąbrowska była rozczarowana kontaktami z rodziną Kossaków. W październiku 1935 roku zanotowała w Dziennikach: „[...] wieczorem u Kossaków (Wojciech) [...]. Że też taki świat poczciwych mamutów i wsteczników zachował się gdzieś jeszcze. Nie mówiąc o inteligencji! Dość powiedzieć: Jedynym błędem rządu jest to, że »zniszczył ziemiaństwo (?). [Juliusz] Poniatowski to szkodnik. Nieszczęście, że drugi raz wszedł do rządu. Napoleon to największy bohater świata - oczywiście Napoleon-cesarz. W końcu pani Kossakowa: (obaj bliźni bracia Kossakowie, Wojciech i Tadeusz pożenili się z dwiema siostrami Kisielnickimi): „Ja się w ogóle nie uspokoję, dopóki nie będziemy mieli króla«. Dodajmy jeszcze straszliwe bohomazy w pracowni Kossaka, zakupywane przez M[inisterstwo] S[praw] Wojsk[owych] itd. Dodajmy serdeczności, jakimi mnie obsypują (»mon illustre cousine« - Juliusz Kossak był żonaty z Gałczyńska, któraś z moich prababek) i dziwożonowate dziwadło - Lilkę Jasnorzewską - przyjemno-przykry koszmar. Nie wiem, jak ja się z tej znajomości wywinę, ale to obcość tak straszna, że trudno sobie większej wyobrazić (choć Jasnorzewską bardzo lubię)". Zob. Dz. 28 X 1935. 
Nie wiem, od czego zacząć tę pierwszą relację, gdyż już wrażeń jest bardzo dużo. Odjechaliśmy o wpół do drugiej przy dźwiękach Jeszcze Polska nie zginęta i Pierwszej Brygady, granej przez orkiestrę stojącą na galerii Dworca Morskiego, przepełnionej rodzinami służby okrętowej i załogi (nawet dzieci w wózkach). Ładowaliśmy się z górą trzy godziny (od 10-tej), było trochę bałaganu z zaokrętowaniem bagaży, których rzeczywiście wiozą mnóstwo, i to kufrów, wobec których moje dwie walizki wydają się liliputkami. Złapałam jakiegoś starego miłego stewarda (stiuarda), który za półtorej zł przeniósł mi prędko indywidualnie rzeczy do mojej kabiny. W czasie odjazdu niebo poszarpało się w strzępy, morze w kolorach i pianach i wiatr. Po wyjeździe za Hel okręt zaczął przyjemnie huśtać, a ludziska biedni rzygać. Ja natomiast czułam się świetnie, jakby morze było moim żywiołem. Stanowczo stworzona jestem na chłopca okrętowego. Zwiedzałam tedy statek. Moja kajuta znajduje się na trzecim, najmniejszym pokładzie w klasie, którą przy normalnych przejazdach należałoby nazwać 2,99 , a może trzecią klasą. Uwzględniając mój kaprys samotności, dano mi kabinę kiepskawą, wewnętrzną, tj. bez okna na morze, w dzień i w noc oświetloną przez jedną średniej siły żarówkę. Pierwsze wrażenie było przykre, jakby mnie zamknęli w celi więziennej, ale potem oswoiłam się i jakoś urządziłam. Bo mimo to powietrze w kabinie doskonałe. Od strony korytarzyka, wąskiego jak szczelina, są nad i pod drzwiami ażury, przez które wchodzi dosyć świeżego powietrza wtłaczanego sztucznie z góry. Łóżko b[ardzo] wąskie, ale wygodne jak hamak. Szklanka jest, są nawet ramiączka do sukien, ale nie ma szafy. Naprzeciw mnie, drzwi w drzwi, [w] kab[inie] 318 mieszka p. Pawlikowska-Jasnorzewska, która jest bardzo miłe babjo [?] i z tych moich entuzjastek, co mnie aż w rękę całują (jak Mira Zimińska, do której p. Pawl[ikowska], mimo typu ziemiańsko-rodzinnego, jest z czegoś odrobinę podobna). [Na marginesie listu:] Stary Kossak, okazało się, nie jedzie. Jej mąż, mimo że lotnik, cały dzień wczoraj chorował. Wszedłszy do nich z cukierkami Wandy, zastałam go w łóżku i widziałam tylko chłopięcą, śmiejącą się, dosyć przyjemną twarz. Ta jadalnia B do której mnie przydzielono jest ponura i niezbyt przyjemna, ale na wejście p. Appenszlakowa, która też jedzie, przeniosła mnie do sali A, która jest ładna, wesoła, lepiej obsłużona i w ogóle daleko lepsza. Statek „Kościuszko” jest to stary wysłużony grat rosyjski, w gruncie rzeczy straszne pudło, teraz dopiero odnowione, przebudowane, „przypudrowane”, jak mówi kapitan Borkowski. Statek jest mały, p. Appenszlakowa nazywa go „Kopciuszko” albo „Tremolino”, ponieważ stale z lekka dygocze, co widać nawet po moim niepewnym piśmie. Pokłady środkowy i szalupowy są dobrze urządzone, mają salony, bary i fumoiry, kajuty są znacznie wytworniej urządzone. Na tych też tylko pokładach mają pewną rację poprzywożone przez damy stroje, bez których jednak można się tu świetnie obejść, bo na pokładzie potrzebuje się głównie chustek do owinięcia głowy, swetrów i koców. Dużo pań pobrało futra, i te miały najwyższą rację, jest bowiem zimno. Ja jednak dzięki wziętym ciepłym majtkom i płaszczowi nie marznę. Wczoraj po lunchu, który przynajmniej połowa pasażerów natychmiast oddała 
40 morzu, wynajęłam leżak i koc i dobrze owinięta do 6-tej leżałam na pokładzie. Morze było nieprawdopodobne w efektach, a towarzyszące nam ciągle ogromne stado mew, skrzypiących jak spróchniałe drzewa, dawały niezwykłe pole do obserwacji ich lotów. Było ich trzy gatunki. Duże ze skrzydłami czarnymi albo ciemnoszarymi, małe szarawe i małe czysto białe. Pod wieczór morze się uspokoiło i aż dotąd statek idzie jak po Wiśle.

45 Prócz pani Pawlikowskiej, Appenszlakowej (będącej moją opatrznością i b[ardzo] miłą) i Krawczyńskiej, spotkałam tu Rymkiewicza (Szulca) prozaika, pisarza i adwokata, brat-łatę, lubiącego rozmowy literacko-psychologiczne. Przystał do mnie na kształt p. Jasińskiego, ale jest usłużny, więc pożyteczny, gdy trzeba przynieść pled lub coś podobnego. Poza tym niegroźny, ile że pod względem „wdzięków” przedstawia mniej

50 więcej to samo co p. Edward. Przed trzema miesiącami urodził mu się syn i młoda żona wyprawiła go po tym przejściu na wakacje.

Za trzy godziny wpływamy do Kanału Kilońskiego, gdzie mamy spotkać się z „Piłsudskim”. Może uda mi się przesłać depeszę do Kazia, by zatelefonował do Ciebie po powrocie.

55 To chyba na razie wszystko. Zła jestem tylko, bo „malowanie” się opóźnia i przyjdzie może akurat, kiedy będzie ciepło i czas na jasne suknie, a może na Cádiz. Ale poza tym czuję się bajecznie dobrze, bardzo się cieszę, że się jednak zdecydowałam. Naprawdę nie ma to jak podróż morzem. Żadna inna nie może się z tym porównać. Wczoraj wieczór dzięki Pawlikowskiej, która już jechała tym statkiem, poznałam kapitana

60 Borkowskiego. Jest to pyszny typ wilka morskiego (służby rosyjskiej), zawsze podchmielony, z czerwonym nosem, doskonale opowiada, mieszając wszystkie języki, a zna ich jak polski, trzynaście. Między innymi powiedział wczoraj: „Tak tak, navigare nesesse est, vivere non est nesesse" - notuję fonetycznie, jak słyszałam.

Całuję Cię. Zatelefonuj o gazetę do Laluni. M.

Papier listowy z nadrukiem s/s „Kościuszko”, Gdynia - Ameryka, Linie Żeglugowe S.A.; [adres:] WPan Stanisław Stempowski, Warszawa, Polna 40 m. 31, Polska Polen; [stempel pocztowy:] Agencja Poczt.-Tel. s/s „Kościuszko”, 11 IX 1935; [na kopercie numer oraz data dopisane ręką Stanisława Stempowskiego:] 3; 11 IX 35. Muz. Lit., sygn. 2050, t. 4, k. 107-108 (koperta k. 109); odpis masz., sygn. 2051, k. 93-94 [tu liczne zmiany redakcyjne i opuszczenia].

\section{Objaśnienia}

* Numer dopisany na kopercie ołówkiem ręką Stempowskiego. stra Magdaleny Samozwaniec, poetka, dramatopisarka

jak Mira Zimińska - Mira Zimińska-Sygietyńska (1901-1997), aktorka, reżyser. Dąbrowska poznała ją w 1932 roku w Jaworzu. Pisała wówczas do Stempowskiego: „Poznałam już p. Zimińską, która rzuciła mi się niemal w objęcia, mówiąc, że jest moją straszną adoratorką i że mnie kocha, że wtedy, kiedy byliśmy w Ateneum, ona wiedziała, że ja jestem w teatrze i miała straszną tremę (?!). To zupetnie bajka o zającu i żabie. Ktoś ma przede mną tremę!" (list z 30 IV 1932); „Zimińska jest zupełnie szaloną kobietą, a raczej szalonym łobuzem w stylu raczej naszej Wierzejskiej. Mnie ukochała czegoś, całuje mnie po rękach, po nogach, mówi łobuzerskim żargonem. Któregoś wieczora zaprowadziła nas wszystkich do wędrownego cyrku, który rozbił namioty przed apteką. Było to widowisko zupełnie jak u rybałtów z XIII wieku" (list z 5 V 1932).

24-25 Jej mąż, mimo że lotnik - w 1931 roku Maria Pawlikowska wyszła po raz trzeci za mąż za Stefana Jerzego Jasnorzewskiego (1901-1970), porucznika lotnictwa. Odbywali wspólnie wiele zagranicznych podróży m.in. do Włoch, Turcji i Afryki. 
25 z cukierkami Wandy - Wanda z Kociełtów Dąbrowska (1884-1974), nauczycielka, działaczka oświatowa, docent bibliotekoznawstwa, bibliograf, żona Wacława Dąbrowskiego. Była nauczycielką na pensji Pauliny Hewelke w Warszawie, gdzie uczyła się młoda Dąbrowska. Swojemu szwagrowi i jego żonie pisarka poświęciła obszerne wspomnienie. Zob. DzU, t. 3, s. 65 i nast.

29-30 jest to stary wysłużony grat rosyjski - s/s "Kościuszko” został zbudowany dla armatora rosyjskiego pod nazwą "Caryca”. W czasie pierwszej wojny światowej pływał jako transportowiec wojskowy. W 1930 roku został zakupiony przez Polskie Transatlantyckie Towarzystwo Okrętowe, pływał pod nazwą „Kościuszko” na liniach nowojorskiej i lewantyńskiej oraz jako wycieczkowiec.

31 jak mówi kapitan Borkowski - Eustazy Borkowski (1887-1960), kapitan żeglugi wielkiej, w dwudziestoleciu międzywojennym dowodził polskimi transatlantykami, w tym od 1931 roku s/s „Kościuszko”; w 1934 roku na tymże okręcie przywiózł do Polski cztery bizony jako dar polonii kanadyjskiej dla prezydenta lgnacego Mościckiego. Jest bohaterem zbioru opowiadań Karola Borchardta Szaman morski (1985).

34 fumoira - palarnia

46 spotkałam tu Rymkiewicza (Szulca) - mowa o Władysławie Rymkiewiczu (1900-1984), powieściopisarzu, synu Bronisława Szulca i Ireny z Rymkiewiczów, ojcu Jarosława Marka Rymkiewicza, poety, prozaika, historyka literatury. Ukończył prawo na Uniwersytecie Warszawskim i od 1929 roku prowadził własną kancelarię, równocześnie rozwijając twórczość literacką.

48 p. Jasińskiego - Edward Jasiński, rejent z Winnicy koło Garwolina, admirator twórczości Dąbrowskiej. Pisarka poznała go w 1930 roku w Jaworzu. Pisała o nim, że stał się „wiernym, wypróbowanym niezawodnym, ofiarnym przyjacielem, zawsze czujnym na to, czyśmy czego nie potrzebowali i zawsze gotowym śpieszyć nam radą i pomocą". Zob. DzU, t. 3, s. 134 Jego korespondencja z Dąbrowską urywa się na początku 1944 roku, być może z powodu śmierci Jasińskiego.

$53 \quad z_{\text {„ }}$ Piłsudskim” - „Piłsudski”, właśc. ORP „Komendant Piłsudski”, pierwotnie okręt „Łun” zbudowany w 1916 roku w fińskiej stoczni dla rosyjskiej marynarki wojennej, w 1920 roku zakupiony przez Polską Marynarkę Wojenną i ochrzczony mianem „Komendant Piłsudski”. W związku z rozpoczęciem rozmów o kapitulacji ORP 1 października 1939 roku „Komendant Piłsudski” został zatopiony przez załogę w porcie w Helu. Po zajęciu portu przez Niemców okręt został wydobyty i wcielony do Kriegsmarine pod nazwą „Heisternest” jako jednostka doświadczalna, w 1943 roku zatopiony przez bomby lotnicze w porcie Nantes.

przesłać depeszę do Kazia - Kazimierz Wierzyński płynął w tym czasie do Gdyni na ORP „Komendant Piłsudski”. Por. list Z 11 IX 1935.

55 „malowanie” - tak Dąbrowska określała comiesięczne dolegliwości kobiece

56 Cádiz - Kadyks, miasto w południowo-zachodniej Hiszpanii, w regionie Andaluzja

62-63 „Tak tak, navigare nesesse est, vivere non est nesesse” - właśc.: „Navigare necesse est vivere non est necesse” (łac.) "Żeglowanie jest rzeczą konieczną, życie nie jest koniecznością". Słowa wypowiedziane przez rzymskiego wodza i imperatora Pompejusza Wielkiego do kapitana okrętu, który wobec nadciągającej burzy wahał się, czy wypłynąć w morze. Sentencję tę odnotował Plutarch i dlatego to jemu jest niesłusznie przypisywana.

do Laluni - nie udało się ustalić, o kogo chodzi

[z pokładu s/s „Kościuszko”] 11 IX [193]5 poł.

Płyniemy przez Kanał Kiloński, niby przez wąziutką cichą rzekę. O dwa metry przed sobą, leżąc na leżaku, mam brzeg zielony, płaski, pełny zarośli, wiosek, dróg, po których chodzą i jeżdżą ludzie. Wioski zupełnie sielskie. Przed godziną minęliśmy „Piłsudskiego”, ale w takim tempie, że choć był tuż, nie było mowy zobaczenia Kazia i dania znać, żeby zatelefonował na Polną. A radiodepesza okazała się zbyt kosztowna. Teraz jest już ciepło, prawie gorąco. 
Co za ponury $[\ldots]$ niemiecki pomnik.

[Dopisek pod fotografią pomnika:] Holtenau. Wjazd do Kanału.

[Pocztówka niemiecka z fot. pomnika; adres:] WPan Stanisław Stempowski, ul. Polna 40 m. 31, Warszawa, Polska; [stempel pocztowy:] Agencja Poczt.-Tel. s/s „Kościuszko”, 11 IX. Muz. Lit., sygn. 2050, t. 4, k. 106; odpis masz., sygn. 20151, k. 92-93 [tu drobne opuszczenia].

\author{
Objaśnienia \\ * Numer dopisany na kopercie ołówkiem ręką Stempowskiego. \\ 5 Żeby zatelefonował na Polną - w 1918 roku Dąbrowska wraz z mężem Marianem zamieszkali przy ul. Polnej 40 m. 31. \\ Pisarka pozostała tam także po śmierci męża w 1925 roku, a w 1927 roku wprowadził się do niej Stanisław Stempowski. \\ 8 niemiecki pomnik - na awersie fotografia monumentalnego pomnika z podpisem: Marine-Ehrenmal Laboe. 1. Bauab- \\ schnitt Entw[urf] G.A. Munzer, Düsseldorf. Höhe über dem Meeresspiegel 85 m.
}

Wysłałam do Ciebie kartę i list z Kanału Kilońskiego, nie wiem, jak to doszło. Staliśmy dość długo w Holtenau przed śluzą, podobno tam zdano pocztę (ze znaczkami polskimi) i miał ją zabrać „Piłsudski”. Ten list wrzucę już jutro sama z Antwerpii albo Brukseli. Czuję się w dalszym ciągu prześwietnie, mimo że malowanie się już zaczęło i trochę boli.

5 Ale nastrój przepyszny. Pogoda cudowna, morze, nawet to Północne - ciche i błękitne, ciepło już tak, że nie potrza się owijać i zabezpieczać. Wczoraj o 10-tej płynęliśmy już nie Kanałem, tylko szerokim ujściem Elby, o 11-tej wypłynęliśmy na szerokie morze. Pani Appenszlakowa ciągle walczy o przeniesienie mnie do sali A, chociaż ja się już oswoiłam z B i nawet znajduje upodobanie w „dołach” okrętowych, gdzie towarzystwo

10 jest skromniejsze i bardziej ludzkie, podczas gdy na górze jest pełno snobów, bourgeois, a nawet jakichś hrabin. Tam na dole siedzę przypadkowo w towarzystwie literatów, mianowicie tego młodego humorysty Marii Artura Swinarskiego, który pisuje, zdaje się, w „Prosto z Mostu”, jakiegoś karykaturzysty i Rymkiewicza, który poza tym znalazł sobie już jakiś flirt śród pasażerek i przestał się mnie trzymać, co mu mam za dobre. Prosił

15 mnie nawet o dyskrecję, wobec tego, że mamy wspólnych znajomych (Erazmów), więc nie wspominaj im o tym. Jest to typowy „łowca przygód podróżnych”, w czym przypomina Janka Miłkowskiego. Ta cecha jest dla mnie w „mężczyźnie” czymś b[ardzo] odstręczającym. Ale najzabawniejsze to, że moim sąsiadem z prawej strony okazał się ksiądz Tokarczyk z Płonnego, którego znałam tylko z kościoła i z opowiadań Heli, ale który

20 mi posłużył za żywcem wzięty model Księdza Filipa. Jest to potężnej struktury jegomość o czerwonej dobrodusznej twarzy łagodnego pijaka. Poznał mnie z podobieństwa do 
Heli Hepkowej. Nieprawdopodobnie mnie to śmieszy, że siedzi koło mnie i nie wie, że przejrzałam go już na wylot i utrwaliłam w literaturze na zawsze. Ludzie tu coraz więcej moją osobą interesują [się] i gdy przechodzę, oglądają się za mną, co mnie mocno krępuje. Ale spotykam też wzruszające objawy. Moją sąsiadką w kabinach jest jakaś chuda paniusia, która też jest w kabinie sama, tylko że przypadkiem. Otóż wczoraj w Holtenau oświadczyła mi się z adoracją, a dowiedziawszy się, że ja mam kabinę bez okna, ofiarowała się ze mną zamienić, gdyż ona ma okienko na morze. Bardzo nawet nalegała, „bo dla pani to światło może mieć wielkie znaczenie, a z tego, że ja je mam, nic nikomu nie przyjdzie”. Strasznie podziękowałam, ale oczywiście odmówiłam, nie chcę w ten sposób wykorzystywać zachwytu nad Nocami i dniami. Do swojej kabiny zresztą już się całkiem przyzwyczaiłam. Najwięcej przeszkadzała mi myśl, że rano nie będę wiedziała, czy to już dzień, czy jeszcze noc. Ale zauważyłam, że w suficie jest przez całą długość szpara między spojeniem belek. Otóż ta szpara rano robi się jasna - srebrzysta i po tym poznaję, że już dzień, że można zapalić światło, zobaczyć godzinę i ewentualnie wstawać. Śniadanie (świetne) jem już o wpół do ósmej.

Ten por. Jasnorzewski jest dosyć prostak, dziś rano zrobił awanturę stewardessie (stiuardessa - służąca po prostu), że nie chcieli mu sprowadzić o 7 rano doktora do masażu nogi, w której ma po jakimś wypadku reumatyzm. Wymyślanie było w doskonałym stylu kordegardy z wyrażeniami „pies mordę lizał doktorowi” itp. W dodatku kazał sobie do łóżka podać śniadanie, czego już zgoła nie rozumiem, bo jak można jeść w ciasnej zimnej klatce, kiedy w salach jadalnych o tyle przyjemniej.

Służba, a nawet oficerowie nie są tu uprzejmi dla pasażerów, to swoją drogą, ale ja znalazłam już drogę do uprzejmości, oczywiście przez portmonetkę. Okazała się niezawodna. Twarze zaraz się rozjaśniły i usłużność wzmogła do niezmiernych granic. Może też i mój system serdecznej i uśmiechniętej grzeczności działa tak, że dziś już widzę wielką różnicę w traktowaniu moich zapytań i próśb, gdy wczoraj byłam zdumiona szorstką oschłością.

To już na razie wszystko.

Najserdeczniej całuję,

M.

[List bez koperty; rękopis]. Papier listowy z nadrukiem s/s „Kościuszko”, Gdynia Ameryka, Linie Żaglowe S.A. Muz. Lit., sygn. 2050, t. 4, k. 110-111; odpis masz., sygn. 2051, k. 94-95 [tu drobne zmiany stylistyczne i opuszczenia].

\section{Objaśnienia}

\section{* Numer dopisany ołówkiem ręką Stempowskiego.}

młodego humorysty Marii Artura Swinarskiego - Artur Maria Swinarski (1900-1965), poeta, komediopisarz, satyryk, ttumacz, scenograf, publikował w tygodniku "Prosto z Mostu” redagowanym przez Stanisława Piaseckiego w latach 1934-1938. Jednocześnie w latach 1934-1935 i 1938-1939 zamieszczał swoje prace w „Wiadomościach Literackich”, zwalczanych przez to pismo.

15 Erazmów - Erazm Samotyha (1886-1963), pedagog, działacz kulturalny, wolnomularz, i jego żona Aniela z Miłkowskich (1876-1965), historyk sztuki, pedagog, działaczka oświatowa, byli przyjaciółmi Dąbrowskiej od czasu studiów w Bruksel w latach 1907-1910, świadkowali też na ślubie Marii z Szumskich i Mariana Dąbrowskiego w 1911 roku. Postać młodej Samotyhowej jako Tyhańskiej wprowadził Juliusz Kaden-Bandrowski do autobiograficznej powieści Proch (Kraków 1913) Aniela była spowinowacona z Zygmuntem Miłkowskim (pseud. Teodor Tomasz Jeż), a przez pierwszego męża, Zdzisława Jełowickiego, ze Stanisławem Jełowickim z Sabinowa, mężem kuzynki Dąbrowskiej.
Ludzie tu coraz więcej moją osobą

interesują [się]

i gdy

przechodzę, oglądają się za mną, co mnie mocno krępuje 
17 przypomina Janka Miłkowskiego - Jan Miłkowski (1872-1936), brat Anieli Samotyhowej, działacz oświatowy. W 1906 roku założył Wyższe Kursy Pedagogiczne dla Kobiet. W 1916 roku został inspektorem szkolnym w Opocznie, Sochaczewie, Grodzisku i w powiecie warszawskim; w tym czasie kursami kierowała jego siostra.

19 ksiądz Tokarczyk z Płonnego - ksiądz Ludwik Tokarczyk (1887-1948), przed wojną proboszcz parafii św. Jakuba Apostoła w Płonnem (wieś w województwie kujawsko-pomorskim). Po wybuchu drugiej wojny światowej był więziony przez Niemców w obozie przejściowym dla księży w Oborach.

Hela - Helena z Szumskich Hepke (1891-1969), młodsza siostra Dąbrowskiej, pierwowzór Emilki w Nocach i dniach. Jej mąż, Stanisław, był administratorem wielu majątków, w tym majątku Łempickich w Płonnem koło Golubia Pomorskiego. Pisarka jeździła tam na wypoczynek w latach 1925-1928.

Jestem na wystawie światowej, która jest b[ardzo] wesoło i ładnie urządzona. Zwiedzam Brukselę indywidualnie z p. Appenszlakową. Poszłyśmy do poselstwa, gdzie spotkałam Iwaszkiewicza. Jack[owski] dał nam auto, którym objechałyśmy miasto. Dziś w nocy wyruszamy do Cadixu.

[Pocztówka z reprodukcją przedstawiającą Ulicę Starą w Brukseli; adres:]

WP. Stanisław Stempowski, Warszawa, ul. Polna 40 m. 31, Pologne; [stempel pocztowy:] Bruxelles Exposit. Brussel Tentoonst. 13 IX 32. 16-16. Muz. Lit., sygn. 2050, t. 4, k. 112; odpis masz., sygn. 2051, k. 95.

Objaśnienia

* Numer dopisany ręką Stempowskiego.

1 Jestem na wystawie światowej - Wystawy Wszechświatowe, prezentujące dorobek kulturalny, naukowy i techniczny krajów i narodów świata, odbywają się cyklicznie od 1851 roku w różnych stolicach, w Brukseli w latach 1897, 1910 i 1935. Dąbrowska zwiedzała także wystawę w 1910 roku, po czym ogłosiła kilka reportaży w „Gazecie Kaliskiej” (1910, nr 110, 169, 172, 173 i 212) i „Zaraniu” (nr 34 i 35).

$2 \quad$ z p. Appenszlakowa - pobyt w Brukseli mógł być sentymentalną podróża pisarki do czasów studiów i związku z Marianem Dąbrowskim, przyszłym mężem. W Dziennikach zapisała: „Nie udała mi się ta Bruksela, gdzie powinna bym i mogłabym być tylko sama". Zob. Dz. 13 IX 1935

3 Iwaszkiewicza - z ramienia Ministerstwa Spraw Zagranicznych Jarosław Iwaszkiewicz w latach 1932-1935 pełnił funkcje sekretarza poselstwa polskiego w Kopenhadze, a od maja do jesieni 1935 roku w Brukseli

Jack[owski] -Tadeusz Gustaw Jackowski h. Gozdawa (1889-1972), dyplomata, poseł w Brukseli, Luksemburgu i Berlinie. Wnuk Maksymiliana, ojciec Tadeusza Maksymiliana, grafika. W okresie międzywojennym był dyrektorem departamentu w Ministerstwie Spraw Zagranicznych, w latach 1929-1937 posłem nadzwyczajnym i ministrem pełnomocnym II klasy przy Rządzie Królewsko-Belgijskim. Jego żona Anna prowadziła we Wronczynie znany w okresie międzywojennym salon artystyczno-literacki. Opublikował m.in. wspomnienia W walce o polskość (Kraków 1972). 
[z pokładu s/s „Kościuszko”] 14 IX 35 rano

Przy wyjeździe z Morza Północnego

na kanał La Manche

Wczorajszej nocy o godz[inie] 1 stanęliśmy w Antwerpii. W Skaldę wpłynęliśmy już o 6-tej wieczór i jeszcze przed zmierzchem ukazały się białe diuny Holandii - krajobraz znany mi i jedyny w swoim rodzaju. Około 9-tej mijaliśmy Vlissingen, miejsce, gdzie wylądowali Agnieszka z Marcinem, które jednak teraz inne mi się wydało, a przede wszystkim zawstydziłam się, że nie pamiętałam, że ten port jest w ujściu rzeki, co prawda tak szerokim, że drugiego brzegu ani na lekarstwo nie widać, poznaje się to tylko po gładkości wód. We Flessyndze [właśc. Vlissingen] stanęliśmy na minutę i na statek nasz weszli dwaj piloci belgijscy, którzy według morskich obyczajów sprawdzają dokumenty statku i doprowadzają go do portu. Rozmawiałam z nimi, byli to dwaj Flamandzi, mówiący płynnie, ale niepoprawnie po francusku. Cały czas opowiadali o swej królowej Astrid, podkreślając co parę zdań „que c'était une reine démocrate, une vraie démocrate; elle se promenait dans les rues avec son gosse sur le bras, elle était tout à fait comme nous autres, hein".

Wycieczkę do Brukseli postanowiłyśmy z panią Appenszlak odbyć indywidualnie, kosztowało nas to kilka złotych taniej niż oficjalna wycieczka zbiorowa.

13-go września o 8-ej rano wyjechaliśmy świetną koleją elektryczną (śliczne wagony), bilet powrotny do odległej o jakieś 80-100 km Brukseli kosztował 15 fr[anków] tj. 3 złote, to jest mniej niż tam i z powrotem koleją z Warszawy do Świdra, a nie była to cena ulgowa, tylko zwykła tutejsza cena biletów i [jeszcze?] szybkość około $90 \mathrm{~km}$ na godzinę. Zachwycił mnie też brak wszelkich formalności. Przecież przybyliśmy z zagranicy i jechaliśmy w głąb kraju, nigdzie nikt nie sprawdzał dokumentów, nikt o nic nie pytał, żadnych formalności celnych, walutowych itp., żadnych żandarmów ani policjantów. Przez cały czas pobytu na terenie Belgii widziałam tylko dwóch oficerów na ulicy. Wszędzie największa swoboda uprzejmości, życzliwości, doprawdy to jeden z najprzyjemniejszych i najbardziej wolnych, demokratycznych krajów w Europie. Miasta mają widać b[ardzo] daleko posunięty samorząd, bo gdy przy wyjeździe z Brukseli o 7-mej wszystkie sklepy były już zamknięte, w Antwerpii około 9-tej, mnóstwo ich było jeszcze otwartych. Wszędzie mnóstwo pysznych owoców, na wózkach sprzedają brzoskwinie wielkości sporych pomarańczy i niewymownego smaku po 8 fr[anków], tj. 1 zł 60 gr za kilo, a na kilo idzie ich osiem. Kilo wspaniałych winogron po tej samej cenie. W Brukseli przybyliśmy do Jackowskiego, który przyjął mnie momentalnie i b[ardzo] uprzejmie i użyczył nam na trzy godziny swego auta. Spotkałam tam również Iwaszkiewicza, który jest sekretarzem poselstwa.

Szofer tego auta, Belg, imieniem Beniamin, okazał się tak czarującym, inteligentnym człowiekiem, że czułam się w jego towarzystwie znacznie lepiej niż w towarzystwie wyżej wspomnianych dygnitarzy. Jest już siedem lat w poselstwie, ale po polsku nie umie, gdyż jak twierdzi, jest tak niezdolny do języków, że nawet po flamandzku nie mógł się nauczyć. Obwożąc nas po mieście, zachwycał się, że ja tak świetnie wszystko pamiętam. Zapytał mnie, czy to ja w zeszłym roku przysłałam depeszę po śmierci króla i czy ja należę do polskiej Akademii Literatury, bo słyszał, że tam jest jedna kobieta. Kiedy mu wyjaśniłam różnicę między nazwiskiem Nałkowska i Dąbrowska, zapytał, czy 
to jest nazwisko bohatera pieśni „Jeszcze Polska nie zginęła”. Prócz Sienkiewicza zna po francusku Sieroszewskiego i zachwyca się książką jego À la lisière des forêts ( $\mathrm{Na}$ kresach lasów). Z czarującym tym szoferem pokazałam pani Appenszlakowej najgodniejsze widzenia punkty Brukseli. Potem zawiózł nas na wystawę, dzięki czemu nie płaciłyśmy wstępu, gdyż auta dyplomatyczne mają wolny wjazd. Wystawa jest b[ardzo] pięknie urządzona, zwłaszcza przecudne są fontanny, polski pawilonik więcej niż skromny, prawie nędzny, nie pochwalono się nawet takimi rzeczami jak Janowa Dolina lub nasze aeroplany Challenges'owe, a wystawa jest $\mathrm{b}$ [ardzo] tłumnie zwiedzana. Bruksela wskutek niskiego kursu franka belg[ijskiego] jest dla nas b[ardzo] tania. Świetny obiad (w restauracji na wystawie) z białym winem mozelskim i lodami kosztował 15 fr[anków], tj. 3 zł, u nas kosztowałby najmniej 7 lub 8, jeśli nie 10 .

Dziś o $1 \mathrm{w}$ nocy wyruszyliśmy w dalszą drogę, zbudziło mnie warczenie i dygotanie motorów. Jest znowu zimniej, morze jest szare i z lekka spienione, ale statek mimo to idzie gładko. To już na razie wszystko. Podróż na statku coraz więcej mi się podoba.

55 Nie ma tu ani momentu nudy, która zawsze ogarnia w czasie jazdy koleją, człowiek się zadomawia i mieszka w rodzaju oderwanej od wszystkich głupstw i trosk świata republiki. Wczoraj z wystawy wysłałam Ci list i dwie karty, ten list wyślę dopiero z Cadixu. Ciekawa jestem, co w domu, czy łazienka już jest [...].

Ściskam Cię i całuję,

Za list i depeszę z serca dziękuję.

[List z kopertą; rękopis]. [Dołączony fragment koperty z adresem wypisanym ręką Stempowskiego:] Mme Marie Dąbrowska, S/S „Kościuszko”, c/o Msrs. Baquera, Kusche \& Martin S.A., Apartado 65, Plaza de las Cortez 15, Cadiz, Hiszpania, stemple pocztowe: Warszawa 2, 14 IX [19]35. 17; „Są ludzie i są prace ludzkie tak silne i tak potężne, że śmierć przezwyciężają i obcują między nami. J. Piłsudski”. Muz. Lit., sygn. 2050, t. 4, k. 113-114 (fragm. koperty k. 115); odpis masz.: Muz. Lit., sygn. 2051, k. 96-97 [tu opuszczenia dwóch fragmentów tekstu].

Objaśnienia

3-4 miejsce, gdzie wylądowali Agnieszka z Marcinem - aluzja do sceny z Nocy i dni "que c'était une reine démocrate..." (franc.) - „że była to królowa demokratka, prawdziwa demokratka. Chodziła po ulicach z dzieciakiem na ręku - była zupełnie taka sama jak my wszyscy, no nie?"

czy to ja w zeszłym roku przysłałam depeszę po śmierci króla - pod datą 17 marca 1934 roku Dąbrowska zapisała w Dziennikach: „Umarł tragicznie Albert belgijski, przeżyłam to tak silnie, że wysłałam do naszego poselstwa depeszę: "Je pleure avec toute la Belgique bien-aimée le grand et noble roi Albert« [Opłakuję wraz z całą ukochaną Belgią wielkiego i szlachetnego króla Alberta]. Pierwszy to i ostatni zapewne raz w życiu żałowałam śmierci króla". Albert I Koburg, z zamiłowania alpinista, zginął 17 lutego 1934 roku w czasie wspinaczki skalnej.

42-43 "Na kresach lasów” - W. Sieroszewski, Na kresach lasów. Powieść, Petersburg 1894. Przekład francuski został wydany w 1902 roku, wznowiony w przekładzie Marii Rakowskiej w 1929 roku.

47 Janowa Dolina na Wotyniu - wzorcowa, bardzo nowoczesna (pełna elektryfikacja, kanalizacja, wodociagi) osada zbudowana w latach 1920-1930 przy kopalni bazaltu. Jej koncepcja urbanistyczna była analogiczna do projektu budowanej w tym czasie Gdyni. 
aeroplany Challenges'owe - Challenge (Challenge International de Tourisme), Międzynarodowe Zawody Samolotów Turystycznych, międzynarodowa impreza organizowana przez FAl (Międzynarodowa Federacja Lotnicza) przed drugą wojną światową. Zawody przeprowadzone w 1934 roku zakończyły się zwycięstwem ekipy polskiej.

56-57 republiki - w odpisie maszynopisowym dalsza część listu została pominięta
Wczoraj cały dzień płynęliśmy przez La Manche i Pas de Calais. Widać było z bliska brzegi Anglii, wysokie skiby wapienne, olśniewająco białe, zupełnie jakby okryte śniegiem. Już w Kanale była porządna kołysanka, a dziś kiedy wyjechaliśmy na Atlantyk, buja tak, jak nigdy jeszcze nie zdarzyło mi się tego przeżywać. Ale fala jest długa, wspaniała, i statek pomału dźwiga się i opuszcza jak huśtawka na bardzo długich sznurach. Czuję się znakomicie i prawdziwie wdzięczna Ci jestem, żeś mnie namawiał na tę wycieczkę. Spałam znakomicie, a choć współczuję chorującym (jest ich większość), to muszę przyznać, że statek zyskał bardzo na ich skryciu się po kajutach. Pokłady są puste, rano przed śniadaniem zrobiłam sobie spacer, okrążywszy kilkakrotnie pokład od burty do dziobu, czego przy pogodzie nigdy, ze względu na rozstawione leżaki, nie można zrobić. Całą noc padał deszcz, pokład mokry, niebo jasno popielate, ze smugami gdzieniegdzie złocistości seledynu i różu porannego. Sirocco wieje potężnie, była to doskonała gimnastyka ranna opierać się, chodząc i stojąc, jego podmuchom. Ale jest już ciepło tak, że wystarczyła mi moja sama pidżama.

Zapomniałam Ci napisać, że jadam już w sali A, o co prócz pani Appenszlakowej walczyło jakoby parę innych osób. Natomiast stół w sali B żegnał mnie manifestacyjnymi okrzykami żalu. Tak że, jak widzisz, „popuhajczyk” opływa tu w ludzką życzliwość. Przy naszym stole w sali A siedzi inżynier okrętowy, brodacz, b[ardzo] podobny do dr. Stefana Rudzkiego, starszy marynarz służby rosyjskiej, z którym rozmowy na tematy okrętowe są dla mnie bardzo pożyteczne. Siedzi też prof. Lachs, chemik, którego fotografię możesz zobaczyć w jednym z poprzednich numerów „Wiadomości Lit[erackich]” tam, gdzie był wywiad z profesorami na temat nauki w Sowietach.

Zapomniałam Ci też napisać, co mi mówiła Pawlikowska, że dwa miesiące temu umarł Tadeusz Kossak „szumny major”, ze zgryzoty z powodu Górek dostawszy ataku sklerotycznego (mózgowego). Zofia Kossak-Szczucka mieszka znów z matką w Górkach.

Komunikaty radiowe Pata, które miały być co dzień podawane przez „Gazetkę” okrętową, jakoś nas nie dochodzą, tak że nie wiemy, może to już jest wojna na świecie?

Przesyłam Ci fotografię z pokładu, zrobioną jeszcze na Bałtyku, teraz nie potrzeba się już tak okrywać. Obok mnie siedzi pani Appenszlakowa, a za nią w czarnym palcie Rymkiewicz. Fotografia jest zła, wszyscyśmy wyszli obskurnie, ale jeszcze zabawna. Zdjęcie zrobione jest na rufie, teraz leżę już na dziobie, stąd można obserwować, co się dzieje na mostku kapitańskim. 
Całuję Cię i z radością czekam na chwilę, kiedy w Cadixie w kiosku na liście pasażerów, którzy otrzymali korespondencję, przeczytam swoje nazwisko.

[List bez koperty; rękopis]. Muz. Lit., sygn. 2050, t. 4, k. 116; odpis masz., sygn. 2051, k. 97-98 [tu drobne poprawki stylistyczne].

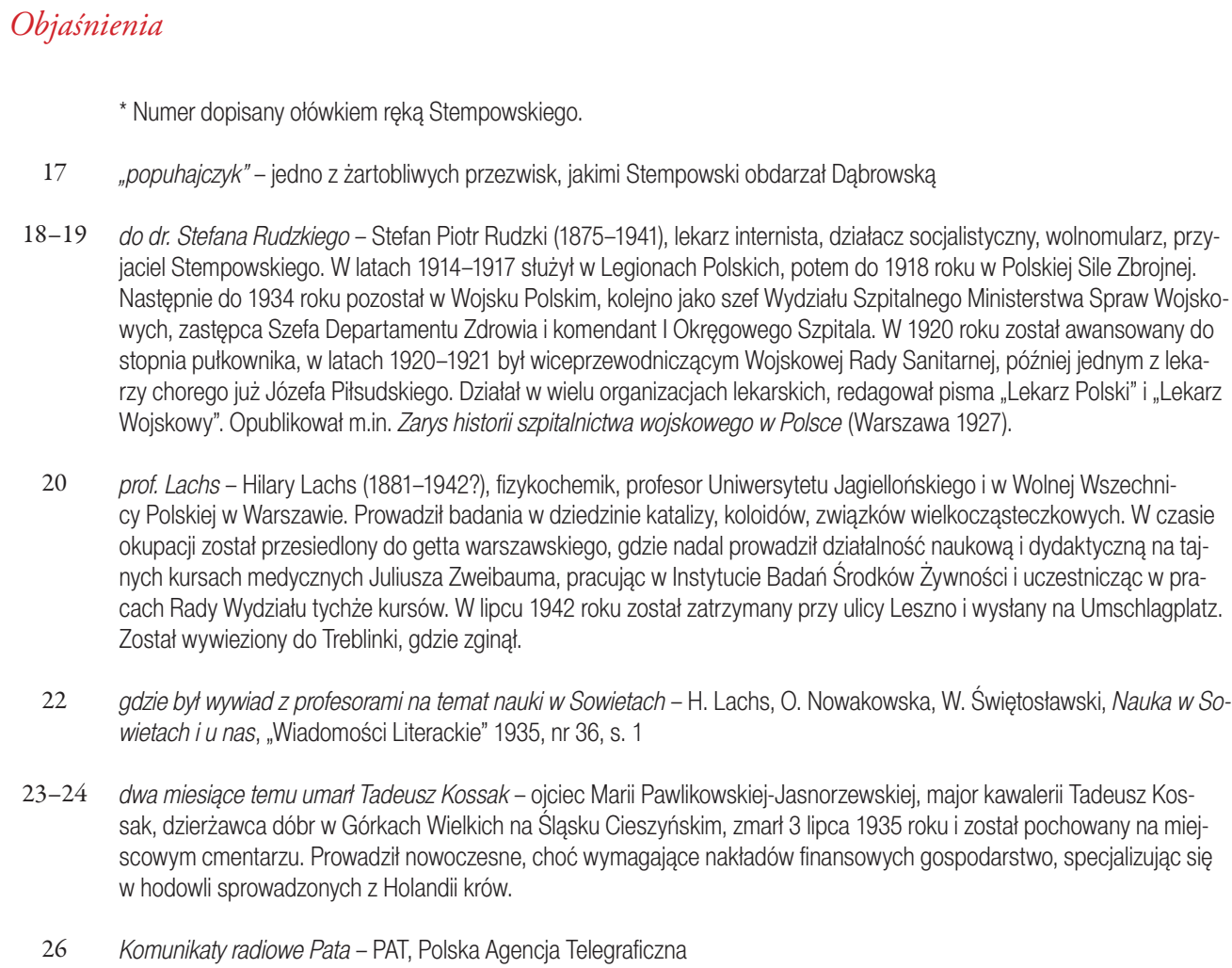

Już tydzień mija od mojego wyjazdu i już z przyjemnością zaczynam myśleć o powrocie. Płyniemy już trzy dni i dwie noce bez przerwy po Atlantyku, i pływać będziemy jeszcze do Cadixu dwa dni i dwie noce. Jest to najdłuższy w tej wycieczce czas przebywania na morzu, ale niestety Atlantyk nie przyjął nas gościnnie. Cały czas huśta szalenie, od czasu 5 do czasu deszcz, to znów pogoda, widoki brzydkiego oceanu wspaniałe, ale w końcu ten ciągły huk, szum, zgiełk, skrzyp i trzask, którym nasz „Kościuszko” reaguje na szturmy wiatru i fal, nuży i chciałoby się, żeby już raz wszystko na chwilę stanęło na miejscu. W salach jadalnych nie ma już żadnego podziału na grupy, gdyż w ogóle siada do stołu zaledwie kilkadziesiąt osób na 487 pasażerów, reszta choruje. Brzegi stołów zabezpieczo- 
no podniesionymi listewkami. Aż żal pomyśleć, że tyle zapłacili, aby rzygać. Już od dwu dni nie widuję nikogo z moich znajomych, wszyscy leżą. Ja nie doświadczam najmniejszych nawet sensacji morskiej choroby, kołysanie jest mi nawet przyjemne, tylko ten ciągły wicher usposabia mnie do snu, a spać nie bardzo jest gdzie, bo do ciemnej kajuty szkoda iść. Za to w nocy wysypiam się jak zabita. Wczoraj cały prawie dzień leżałam na pokładzie. Od czasu do czasu opryskiwała nas fala. Ocean wydymał się i zapadał, było to podobne do wszystkiego raczej niż do wody, raczej do wrzącej lawy lub rtęci. Wczoraj, w niedzielę, była tu msza, odprawiona przez znajdującego się śród pasażerów prałata. Bardzo to było dziwne wrażenie. Odprawia on zresztą cichą mszę co dzień w jednym z fumoir'ów. A teraz w tej chwili raczy się z kapitanem pieprzowo-miętową wódką, koniakiem. Siedzę bowiem w barze A, gdzie są ładne niebieskie meble i miłe biureczko, przy którym zawsze rano piszę.

Całuję Cię i z tęsknotą oczekuję listu w Cadixie.

17 IX wtorek.

Wczoraj po południu lał deszcz, była mgła, a jednocześnie zrobiło się ciepło jak w oran25 żerii. Dziś od rana cudna pogoda, upał, słońce, morze spokojne, wszyscy wczorajsi rzygacze od świtu na pokładzie hałasują, rżą śmiechem i głupkowato dowcipkują. Przed statkiem jak okiem sięgnąć delfiny pluskają się w falach. Minęliśmy już Lizbonę, jutro rano staniemy w Cadixie. Stamtąd albo z Sewilli wyślę te listy.

M. 30

Minęliśmy już Lizbonę, jutro rano staniemy w Cadixie

[List z fragm. koperty; adres:] Stanisław Stempowski, Warszawa, ul. Polna 40 m. 31, Polonia-Pologne; [stempel pocztowy:] Sevilla. 18 Sep. 35. 9; stempel tekstowy w jęz. hiszp. Muz. Lit., sygn. 2050, t. 4, k. 116 (koperta k. 118; na kopercie numer dopisany ręką Stanisława Stempowskiego:] 9; odpis masz.: sygn. 2051, k. 99-100 [tu drobne poprawki i opuszczenia].

\section{Objaśnienia}

* Numer dopisany ołówkiem ręką Stempowskiego.

25-26 Wczoraj po południu lał deszcz, była mgła, a jednocześnie zrobiło się ciepło jak w oranżerii - w odpisie zdanie opuszczone 
$10^{*}$

18 IX [19]35 wieczór, Sewilla

Hotel Angielski

Dziś wysłałam stąd dwa listy napisane na statku, pisane z dnia na dzień. Wrażenia z wycieczki do Sewilli spiszę po powrocie na statek. Jeszcze przed wylądowaniem w Cadixie wręczono mi na statku Twój pierwszy list do Cadixu pisany, drugi mam nadzieję, że dostanę jutro po powrocie na statek.

$\mathrm{Na}$ razie ściskam,

\section{6-tego na Atlantyku uciekliśmy nocą spod sztormu, który zatopił u brzegów Irlandii dwa okręty}

Jestem już dość zmęczona wycieczką.

[Pocztówka z reprodukcją:] Sevilla. Patio de Banderas; [adres:] WPan Stanisław Stempowski, ul. Polna 40 m. 31, Warszawa-Varsovie, Polonia; [stempel pocztowy nieczytelny] Tarieta Postal; [numer dopisany ręką Stempowskiego:] 10. Muz. Lit., sygn. 2050, t. 4, k. 119.

Objaśnienia

* Numer dopisany ołówkiem ręką Stempowskiego.

$18^{*}$

[Sewilla] 19 IX [19]35 8-ma rano

Kochanie moje,

Z każdym dniem coraz mi więcej żal, że z Tobą nie mogę tego mnóstwa wrażeń pochłaniać. 16-tego na Atlantyku uciekliśmy nocą spod sztormu, który zatopił u brzegów Irlandii dwa okręty. Ich sygnały SOS dotarły i na „Kościuszkę”. Wczoraj 18-go nad

5 ranem wpłynęliśmy w strefę upału, w którym pławiliśmy się dotąd. Nie jest jednak niemożliwie gorąco, tylko błoga pogoda o nieskazitelnym niebie. Wczoraj rano o 6-tej obserwowałam wschód słońca, nad zbliżającymi się brzegami skąpanym, godny pióra Conrada. Nie było miejsca w porcie, więc zakotwiczeni sterczeliśmy na morzu i motorówkami dostawali się na ląd. Wyszło stąd wiele bałaganu i pomieszania języków.

10 Pogubiły się wszystkie umówione towarzystwa, w rezultacie ja się znalazłam w towarzystwie doktora okrętowego Ferbera i p. Appenszlakowej i na własną rękę ruszyliśmy w nieznany świat. (Oboje syjoniści, on dla idei został lekarzem okrętowym na „Kościuszce”, który będzie kursował między Konstancą a Palestyna). Najpierw kazaliśmy 
się obwieźć dorożką po Cadixie. Cudowne miasto, białe, mauretańskie, starożytne, roślinność, mury, morze, kwiaty, ludzie, wszystko nie do opisania. I coś niewymownie pachnie w powietrzu. Z Cadixu koleją pojechaliśmy do Sewilli. Po drodze olbrzymie morskie warzelnie soli, potem kraj spalony od słońca, surowy pejzaż, na którym brak tylko Don Kichota na Rosynancie. W drodze zaprzyjaźniłam się z robotnikiem, niezwykle kulturalnym, który poczęstował mnie szklanką dobrego wina i nauczył skręcać hiszpańskiego papierosa. Śniadanie jadł z koszyczka, miał swój widelec, termos, czystą serwetkę. Cały sposób jego zachowania się pełny rycerskości i serdeczności, był jawnym świadectwem dokonanego tu przewrotu. Twarz chuda, z ciemną, jak u El Greca, bródką, ale nadzwyczaj ludzka. Ofiarowałam mu kartkę pocztową z okrętem „Kościuszko”. Rozmowa nasza na migi i pojedynczymi słowami w rodzaju Polacco, turisto itd. była kapitalna. Inni pasażerowie byli dla nas też b[ardzo] serdeczni, w ogóle ludzie tu nadzwyczajnie mili, przy czym w pociagu pasażerowie (3-cia klasa) byli bezinteresowni, w Sewilli mnóstwo żebraków i naciągaczy.

Sewilla jest brzydsza niż Cadix, ale pełna osobliwego życia i nastroju, ludzie zdaje się w ogóle nie kładą się tu spać. Przed hotelem małe dziewczynki tańczą w podartych brudnych łachmanach, widok to żałosny. Sześcio- i siedmioletni chłopcy całymi rzeszami biegną tu za przechodniem, prosząc wszyscy nie o pieniądze, tylko o papierosa. Wszyscy mali chłopcy palą jak stare wygi. Dziesięcioletnie dziewczyny sprzedają bukieciki tuberozy, z zalotnością i znawstwem starych prostyt[utek]. Wszystko jakoś przedwcześnie dojrzałe, a jednocześnie obyczajność tu surowa i staroświecka. Dziś w południe wracamy do Cadixu. Co jest najbardziej upajające, to ta niezwykła pogoda. Wysyłam stąd trzy listy (ten trzeci) i jedną kartę.

Sewilla jest brzydsza niż Cadix, ale pełna

[List z kopertą; rękopis; adres:] WP Stanisław Stempowski, Warszawa-Varsovie, ul. Polna 40 m. 31, Polonia-Pologne; [stempel pocztowy:] Sevilla. 19 Sep. 35; stempel tekstowy w jęz. hiszp. Papier listowy i koperta z nadrukiem: Hotel de Inglaterra, Plaza de san Fernando. Muz. Lit., sygn. 2050, t. 4, k. 120-121 (koperta k. 122); odpis masz., sygn. 2051, k. 100-101.

\footnotetext{
Objaśnienia

* Numer dopisany ołówkiem ręką Stempowskiego; przekreślony nr 11.

22 jak u El Greca - El Greco (1541-1614) malował głównie kompozycje religijne i portrety, w których dążył do uzyskania atmosfery ekstatycznego wizjonerstwa i mistycyzmu religijnego. Przedstawiał postacie odrealnione, o wydłużonych proporcjach.

24 Polacco, turisto (wł.) - Polka, turystka

35-36 Wysyłam stąd trzy listy (ten trzeci) i jedną kartę - w odpisie zdanie opuszczone
} 
Dziś zwiedzałyśmy Alkazar, który jest rzeczywiście cudem, wartym widzenia. Tak żałowałam, że nie oglądam tego z Tobą.

[Pocztówka z widokiem:] Sevilla. Alcázar. Patio de la Yeseria; [adres:] Stanisław Stempowski, ul. Polna 40 m. 31, Varsovie-Warszawa, Polonia-Pologne; [stempel pocztowy:] Sevilla. 19 Sep. 35; stempel tekstowy w jęz. hiszp. Muz. Lit., sygn. 2050, t. 4, k. 123; odpis masz.: sygn. 2051, k. 101.

\section{Objaśnienia}

* Numer dopisany ołówkiem ręką Stempowskiego.

Kochaneńki,

Wczoraj z Sewilli wysłałam Ci dwa listy pisane ze statku i jeden pisany z Hotel de Inglaterra, gdzie nocowałam. Prócz tego kartę z ogrodami Alkazar. Nie wiem, czy co z tego zrozumiesz, bo listów pisanych w pośpiechu w Sewilli nawet po napisaniu nie odczytałam. Nie wiem też, czy pamiętam, co już pisałam, a co jeszcze nie, więc może się będę powtarzać. Najważniejsze, że od Ciebie dostałam w Cadixie oba listy, co było dla mnie wielką radością. Pani z kiosku, gdzie wydaje się pocztę, już mnie zna, i gdy nadchodzę, woła z daleka: „Jest, jest list do Pani”. Niestety, z listów tych widzę, że Ty poza kartkami z dworca w Gdyni, do 14 IX nie dostałeś ode mnie nic, a powinieneś dostać list i kartę wysłane ze statku z polskimi znaczkami, i nadane z Holtenau (przez „Piłsudskiego”) i w Brunsbüttel przez jakiś statek jadący [!] do Gdyni. Ciekawam, czy dostałeś już pocztę z Brukseli (list i kartę). Jutro, w sobotę, a najdalej (z powodu niedzieli) w poniedziałek, powinieneś otrzymać obfitą korespondencję nadaną w Sewilli. Ten list wyślę już z Algieru poleconym. Wracam jeszcze raz do wycieczki hiszpańskiej.

15 Otóż pod pewnym względem nie jestem z niej zadowolona. Dałam się pozbadnąć pani Appenszlakowej, która z mojej opatrzności przeobraża się dzięki swojemu rasowemu tupetowi w mojego „cichego tyrana”. Odmówiła mnie stanowczo od zapisania się na wycieczkę oficjalną, że niby „nie można już wytrzymać w tym tłumie” itp. Istotnie, indywidualna wycieczka byłaby jedyną przyjemną, ale na to trzeba by mieć towarzystwo bliskich sobie ludzi, w przeciwnym razie traci się korzyści urzędowego 
przewodnictwa, które musi wszystko najważniejsze pokazać i objaśnić, a nie zyskuje się nic na towarzystwie. Byłam cały czas z Appenszlakową i owym doktorem okrętowym syjonistą Ferberem. Otóż oni mieli zupełnie inne ideały przed sobą niż ja, inaczej też na wszystko reagowali, szukali cały czas, on białego munduru, ona - hiszpańskiego beretu, i w końcu tak wybierali, że nie zobaczyłam Muzeum, gdzie jest ze 20 Murillów, kilka portretów Goyi i Velasqueza. Taka jestem o to zła, jakby mnie ktoś z czegoś okradł. Za powrotem opowiem szczegółowo, jak to się stało, że nie mogłam tego uskutecznić. Dodajmy, że ów doktór „piękny jak rzé́ba egipska” ma tempo życiowe, wobec którego tempo Czopa jest ekspresem błyskawicznym, łazi jak mucha w mazi, ciagle gdzieś zostawał, senny i znudzony, możesz sobie wyobrazić, jak mnie to irytowało. Mimo te wszystkie minusy wrażeń było dużo niezapomnianych. Ponieważ się okazało, że pociąg z Sewilli, którym o pierwszej w południe mieliśmy wracać na statek, został odwołany, zabraliśmy sześć osób i wrócili taksówką, 160 km cały czas po świetnej, asfaltowanej, gładkiej jak posadzka szosie. Szofera mieliśmy doskonałego i b[ardzo] przyjemnego, a jadąc w ten sposób, widzieliśmy od wewnątrz wszystkie miasta i miasteczka, które poprzedniego dnia mijaliśmy od strony brudnych dworców. Zatrzymaliśmy się nawet na pół godziny w owym Jerez de la Frontera. Jest to biało-różowo-złote, jak wszystko tutaj, miasto. Staliśmy na Plaza Primo de Rivera z jakimś konnym pomnikiem na środku. Chciałyśmy zjeść lodów, ale w żadnej kawiarni nie mogłyśmy dać zrozumieć kelnerom, o co nam chodzi. Dopiero na wyjezdnym z Cadixu dowiedziałam się, że lody nazywają się helados (czyt. jelados). Krajobraz po drodze z Cadixu do Sewilli jest nadzwyczaj osobliwy. Cadix jest zbudowany na rozszerzonym końcu takiej mierzei jak nasz Hel. Wzdłuż tej mierzei idzie tu od portu kolej i szosa, a po obu stronach szumi morze, z jednej strony zatoka, z drugiej olbrzymia fala Atlantyku z przepyszną piaszczystą plażą. Następnie mija się ciągnące się wiorstami ogromne warzelnie soli morskiej, cały system kanałów i basenów, w które przypływ napędza wodę, następnie parującą. Całe góry tej soli, białe jak śnieg, leżą dokoła usypane. Potem zaczyna się pagórkowata spalona iście afrykańskim słońcem pustynia, pełna różnobarwnych urwisk czerwonych, żółtych, płowych. Mnóstwo bodiaków - ostów, podobno jadalnych, spalonych na wiór. Śród tego karawany osłów ślicznie objuczonych. Ich poganiacze w kapeluszach tej formy słomianych. Wszystko razem jak ilustracja do Biblii. Wkrótce potem ziemia staje się żyźniejsza. Pojawiają się laski piniowe krągłych pinii, jakie widzi się u Botticellego, wreszcie coraz większe ilości wspaniałych eukaliptusów. Widać ich całe lasy, szosa kilometrami jest nimi wysadzona, pachną tak, że czuje się mimo pędu auta. Coraz więcej rozległych pól, wygląda to na wielkie majątki jakichś grandów, od czasu do czasu hacjenda, niby nasz dwór, oślepiająco biały lub różowy w ogrodzie pełnym palm, pomarańcz i niebieskich białych, różowych kwiatów. Płoty wszystkie z wspaniałych opuncji, gdzieniegdzie agawy, częściowo nawet i one poschnięte. Między hacjendami nieprzejrzane gaje, ogrody oliwek i pomarańcz, których owoce są zupełnie zielone jeszcze. Najczęściej na glebie czerwonej jak krew, dziwne połączenie tej zieleni z czerwienią, niby we śnie fantasmagorycznym. Potem ziemia robi się płowa, a okolicami całkiem czarna i tłusta. Na wielkich równinach widać ścierniska, sądząc z koloru i z dobroci tutejszego chleba - pszeniczne, dalej ściernia kukurydziane, wreszcie winnice ogromne i pola bawełny, której zbiór się właśnie odbywa i którą wypychają tu poduszki. Tu i ówdzie wioski nędzne jak najnędzniejsze polskie, kryte słomą lub suchą kukurydzą,

bez kominów wszystkie domy. Często gęsto na gołych niczym nieporośniętych lub spalonych nieużytkach stada krów, wołów i owiec, śród których brak tylko Don Kichota, 
walczącego z baranami. Co to bydło je na tej spaleniźnie, nie wiem, ale wszystkie pyski utkwione w ziemi, coś tam widać znajdują.

W Sewilli jest wielki port morski na Gwadalkiwirze, pięknej rzece, która ukazała nam się w różowych i liliowych blaskach meskalowego zachodu. Powietrze przesycone wszędzie masami teraz kwitnącej tuberozy - oszałamiające. Przesyłam Ci dwie akwarelki oryginalne, nawet z podpisem malarza, które kupiłam w Alkazarze za 6 pesetów.

Zapomniałam jeszcze napisać, że przedwczoraj z naszym inżynierem (tym podobnym do Stefana Rudzkiego) zwiedziłam dno statku, maszyny, pompy, piece itp. Trzeba się było do tego ubrać w brązowy kombinezon z grubego brezentu.

W „Gazecie Polskiej” Krawczyńska pisze korespondencje z naszej wycieczki, poproś Wacków, niech Ci wytną i dadzą przeczytać.

[Na marginesie 1 strony:] Mimo jedynych w swoim rodzaju wrażeń, tęsknię za domem, Tobą i cieszę się, że już jesteśmy w drugiej połowie podróży. Pogoda cudowna.

[Na marginesie 2 strony:] Wczoraj w Cadixie marynarz z naszej załogi ledwo wyszedł na ląd, pobił dwu hiszpańskich policjantów, za co nie wiem, bo tak miłej, grzecznej, przyjacielskiej policji jeszcze żem nigdzie nie widziała. Była z tego powodu zaraz sprawa sądowa, nie wiem, czy kapitanowi udało się tego marynarza wydobyć z opałów i zabrać na okręt. Wczoraj w pociągu Hiszpanka z dzieckiem na ręku zabawiała nas pokazywaniem kameleona, którego miała w papierowej torebce żywego.

[List z kopertą; adres:] Mr Stanisław Stempowski, Varsovie-Warszawa, ul. Polna 40 m. 31, Pologne, Europe; recommandé. Exp. Maria Dąbrowska, s/s Kościuszko; [stempel pocztowy:] Alger - Port Alger 21-9 35. Muz. Lit., sygn. 2050, t. 4, k. $124-$ -125 (fragment koperty k. 126); odpis masz.: sygn. 2051, k. 102-103 [tu opuszczony duży fragment tekstu oraz liczne drobne zmiany stylistyczne].

\section{Objaśnienia}

* Numer dopisany ołówkiem ręką Stempowskiego. czony

25-26 gdzie jest ze 20 Murillów, kilka portretów Goyi i Velasqueza - Dąbrowska wspomina Muzeum Sztuk Pięknych (Museo de Bellas Artes) w Sewilli, utworzone w 1841 roku w budynku klasztornym. Posiada kolekcję malarstwa od średniowiecza do początku XX wieku, w tym dzieła Francisco Pacheco, Diego Velazqueza, Bartolomé Estébana Murilla, Juana Valdés Leala i Francisco Zubarána. 


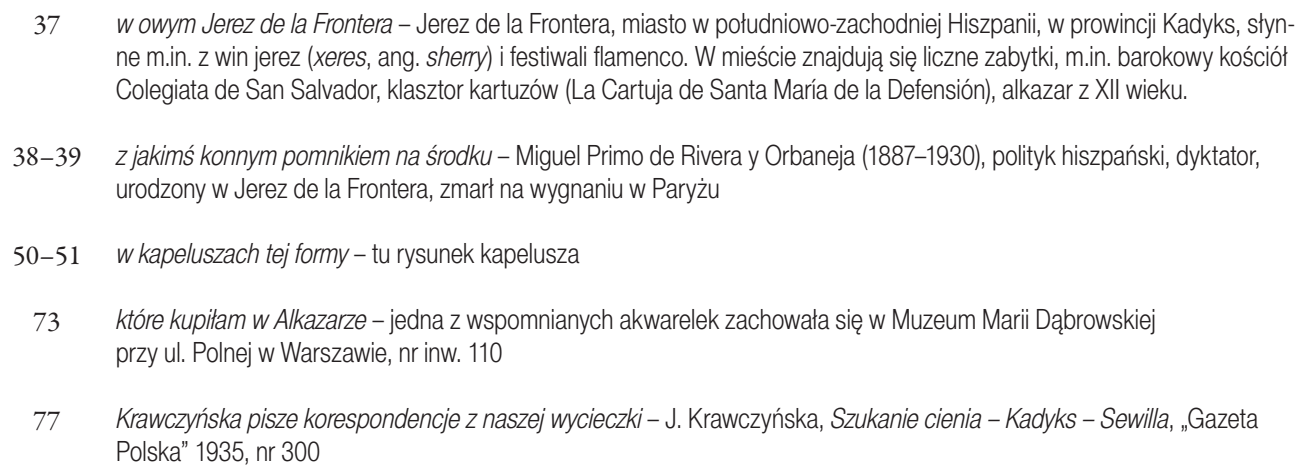

Jak widzisz, Algier jest zwykłym wielkim miastem, które od innych francuskich różni się tym, że ulice ma wysadzone mirtami i pomarańczami. No i Arabów, i dzielnicę arabską i chłopców znanych z tysiąca opisów, którzy nurkując, podnoszą z dna morza rzucony pieniądz. Za chwilę wyślę Ci stąd list poleconym, a Twój list kochany dziś rano otrzymałam, za co dzięki.

M.

[Pocztówka z widokiem:] Algier. Rue Michelet; [adres:] Mr Stanisław Stempowski, ul. Polna 40 m. 31, Varsovie-Warszawa Pologne, Europe; [stempel pocztowy:]

Alger - Port. Alger [data nieczytelna]. Muz. Lit., sygn. 2050, t. 4, k. 127.

\section{Objaśnienia}

* Numer dopisany ołówkiem ręką Stempowskiego.

Piszę już ostatni list, który wyślę z Aten lub Pireusu i który dostaniesz zapewne w przeddzień mojego powrotu, a może już po powrocie. Nie mogę sobie jednak odmówić przyjemności napisania go, bo to najprzyjemniejsza dla mnie chwila na statku. Według oficjalnie ogłoszonego tu rozkładu jazdy przyjadę do Warszawy pospiesznym do Lwowa, 
5 który przychodzi na dolny Dworzec Główny we wtorek 1-go października o godz.

11.10 (23.10) wieczorem. Nie przychodź na dworzec, bo będę się martwić, że się zmęczysz, i nie niepokój się, jeżeli bym tym pociągiem nie przyjechała, znaczyłoby to tylko, że zaszła jakaś zmiana w ogólnie obowiązującym planie. Myślę jednak, że żadna taka zmiana nie zajdzie i że przyjadę tak jak tutaj donoszę. List Twój w Algierze dostałam, stokrotnie dziękuję, mogłeś napisać jeszcze drugi, gdyż staliśmy w tym porcie dwa dni.

Zapomniałam Ci jeszcze napisać, że po wyjeździe z Sewilli był na statku urządzony próbny alarm, na który wszyscy pasażerowie, służba i załoga, musieli prędko wdziać pasy ratunkowe i wybiec na wyznaczone sobie miejsca. Bardzo zabawnie i nawet ładnie w takich pasach się wyglądało. W każdej kabinie są pasy ratunkowe, małe dla

15 dzieci, duże dla dorosłych. Te „ogłoszenia”, które widzieliśmy na fotografii kabiny, są to instrukcje, jak się zachować w razie alarmu, z fotografiami wkładania i zaciągania pasa, i z oznaczonym czerwono miejscem na pokładzie, gdzie trzeba się w razie alarmu udać. Moje miejsce było na rufie z lewej strony. Wszystko to bawi mnie i zajmuje swoją nowością, w ogóle nowość doznanych w tej podróży wrażeń jest ich największą atrakcją.

20 Algier leży nad zatoką w rodzaju Neapolitańskiej, tylko piękniejszą. Jest to olbrzymie miasto, zbudowane półkolem na przestrzeni całego wybrzeża zatoki, amfiteatralnie na b[ardzo] wysokim brzegu, tak że z portu do śródmieścia wjeżdża się windą lub taksówką serpentynami. Pierwszego dnia zwiedzanie miasta odbyłam z oficjalną wycieczką statku i w towarzystwie Rymkiewicza, który jest miłym towarzyszem wycieczki, ale w ogóle

Wszystko to bawi mnie i zajmuje swoja nowością, w ogóle nowość doznanych w tej podróży wrażeń jest ich największą atrakcją zewnątrz, i na wewnątrz stuprocentowym chodzącym banałem, nigdy chyba nie będzie z niego pisarz. Dzielnica arabska jest ciekawa, niewymownie brudna i cuchnąca. Kobiety owinięte w białą (z brudu szara) wełnę, którą przytrzymują rękami pod brodą, ukrywając w takim otworze [tu rysunek] jedno oko. Dopiero po sześćdziesięciu latach życia wolno im pokazywać oba oczy. Widziałam stary dom arabski, zachowany jako mu-

30 zeum b[ardzo] piękny. Życie Arabów i Berberów jest całkiem przydepnięte [!] wspaniałą ekspansją i twardą władzą Francuzów. Algier przypomina swym życiem ulicznym, sklepami, kawiarniami - Paryż. Roślinność zupełnie tak sama jak w Hiszpanii. Mnóstwo platanów, eukaliptusów, mimoz, drzew pieprzowych, rododendronów i magnolii, mało palm i cyprysów. Drugiego dnia postoju również z oficjalną wycieczką pojechałam do

35 Blidy. Jest to wąwóz w górach małego Atlasu, gdzie nad górskim strumieniem żyje mnóstwo małp. Są przez hordy turystów tak oswojone, że przychodzą do ręki po te orzeszki „fistaszki”, które my jemy przypalone w piecu. Łażą po dachu kawiarni, która stoi nad strumieniem, a nawet po stolikach, z których kradną torby z tymi orzeszkami. Niektóre tylko dziksze, uciekały w zarośla. Najciekawsza była droga do tego strumienia. Jakieś

$4050 \mathrm{~km}$ jechaliśmy autokarem po świetnej asfaltowej szosie, krajem tak wysokiej kultury ogrodniczo-rolniczej, że można to tylko porównać z Belgią i Holandią. Szosa wysadzana eukaliptusami i drzewami pieprzowymi, a z obu stron ślicznie uprawne winnice, gaje oliwne i pomarańczowe, olbrzymie plantacje pomidorów, warzyw, jakichś drzew owocowych, zdaje się brzoskwiń czy morel, wreszcie plantacje absyntu i geranium (całe

45 pola), ale jakiegoś geranium podzwrotnikowego, z którego tu robią pachnący olejek. Wszystko to na glebie zupełnie czerwonej, podobnie jak w Hiszpanii. Wobec tej precyzyjnej kultury bez śladu nieużytków na pół pustynna Hiszpania robi raczej wrażenie Afryki, a Afryka Europy. Ostatnie 10 km za miasteczkiem Blida wjeżdża się już w góry i jedzie się równie dobrą szosą, ale nad przepaścią, kamienistą, gdzie w porze deszczów

50 płynie zapewne szeroka rzeka, a teraz tylko wąziutki strumień szafirowy sączy swe wody. Okolicą tą przechodzi jednak kolej, idąca do miasta Oranu. Góry, także czerwone, 
o fantastycznej rzeźbie, są też czerwonawe i gęsto porośnięte nieznaną mi roślinnością, krzewami o twardych listkach. $Z$ powrotem jechaliśmy inną drogą, przez okolicę równie dobrze uprawiona, ale o poletkach już mniejszych, poprzegradzanych płotami z bambusu, którego tu b[ardzo] dużo. I dopiero w tej drodze powrotnej widzieliśmy kilka wiosek arabskich. Nieprawdopodobnie nędzne chaty, a raczej lepianki, okryte trzciną, przypominają znane z kin wioski murzyńskie i wyglądają jak wrzody śmiertelnej choroby, przebijające wątłą skorupę triumfalnej na ciemięstwie opartej cywilizacji francuskiej. Potem jechaliśmy nad morzem, tutejszą Riwierą, pełną wspaniałych miejscowości kąpielowych w rodzaju Nieli i Ostendy, gdzie przyjeżdżają bogaci Francuzi, zostawiając własną Riwierę cudzoziemcom. Po drodze widziałam dużo jaskółek, zapewne naszych, które właśnie tylko co od nas odleciały. Upał był duży, ale do wytrzymania, a w powrotnej drodze przy zachodzie słońca nawet chłodno, tak że włożyłam płaszcz płócienny. Wieczorem Algier wyglądał feerycznie jak stos gwiazdozbiorów spadłych na ziemię. Ateny będę zwiedzać indywidualnie pewno z prof. Lachsem i dwoma jeszcze paniami.

Ściskam Cię i do prędkiego zobaczenia.

M.

W drodze do Blidy w miasteczku Bifusic, gdzie wpadliśmy na chwilę, zgubiłam lub skradli mi chłopcy arabscy portmonetkę z 70 frankami (około 24 zł). Ale i tak mam dosyć jeszcze pieniędzy i część przywiozę nawet do domu.

[List z fragm. koperty; rękopis; adres:] WP. Stanisław Stempowski, Varsovie-Warszawa, ul. Polna $40 \mathrm{~m} .31$, Pologne, Polonia; [stempel pocztowy grecki nieczytelny] 20 IX 35. 12. - [na kopercie numer dopisany ręką Stempowskiego:] 16.

Muz. Lit., sygn. 2050, t. 4, k. 128-129 (koperta k. 130); odpis masz.: sygn. 2051, k. 103-104 [tu opuszczone jedno zdanie oraz drobne poprawki językowe].

\section{Objaśnienia}

* Numery dopisane ołówkiem ręką Stempowskiego.

35

Blida - obecnie Al-Bulajda, miasto w północnej Algierii
Wieczorem Algier wyglądał feerycznie jak stos gwiazdozbiorów spadłych na ziemię

Dziś wysłałam list, nie wiem, czy dojdzie przed naszym powrotem. Siedzimy w parę osób w kawiarni w Pireusie. W Grecji wszyscy prawie mówią po rosyjsku! Poza tym wszystko dobrze. Upał tropikalny. Przyjadę we wtorek o 11.10 w nocy. 
[Pocztówka z widokiem: Athènes. Temple de Thésée; adres:] WP. Stanisław Stempowski, ul. Polna 40 m. 31, Varsovie-Warszawa, Pologne-Polonia; [stempel pocztowy:] [miejscowość nieczytelna] 28 IX 35. 11; [numer dopisany obcą ręką:] 25. Muz. Lit., sygn. 2050, t. 4, k. 131; odpis masz.: sygn. 2051, k. 105 [tu jedno drobne opuszczenie].

Objaśnienia

* Numer dopisany ołówkiem ręką Stanisława Stempowskiego.

Key Words: Maria Dąbrowska, Stanisław Stempowski, letters, cruise around Europe, "Wiadomości Literackie"

Abstract: Sixteen letters written by Maria Dąbrowska during her cruise around Europe on $\mathrm{S} / \mathrm{s}$ „Kościuszko” is a small fragment of the 1052-letter correspondence from the period of 1924-1951 with the writer's long-standing life partner, Stanisław Stempowski, which awaits publication. The letters were used by the writer in that year while publishing Listy z podróży in "Wiadomości Literackie". 